\title{
Justification and Excuse in Article 31(1) of the Rome Statute
}

\author{
Beatrice Krebs*
}

\section{Introduction}

Legal systems typically provide grounds for excluding criminal responsibility in defined circumstances. International criminal law, though not a legal system strictu sensu, is no exception. The Rome Statute of the International Criminal Court (ICC) ${ }^{1}$ in Articles 27, 29, 31-33 recognizes certain grounds on the basis of which criminal liability may be excluded. Professor Fletcher has argued that, in classifying defences, 'the [analytical] model of the common law prevails in the design of the substantive law applicable in the ICC.' Like the common law, and in contrast to civil law systems, international criminal law therefore does not distinguish between defences that excuse and defences that justify otherwise criminal conduct. This paper takes issue with this claim. It argues that the distinction between justification and excuse, though not expressly drawn by the Rome Statute, is vital to a workable taxonomy of the defences in Art. 31 (1), namely lack of capacity due to mental disease or defect, intoxication, self-defence, defence of others and duress. ${ }^{3}$ Once it is realized that a taxonomy based on the distinction is required, this also provides some valuable insights into the correct interpretation of the particularly troublesome 'formula compromise' in Art. 31 (1) (d), which lays down a pressure-related defence that is generally understood to represent an amalgamation of (justificatory) necessity and (excusatory) duress.

\footnotetext{
Lecturer, School of Law, University of Reading.

1 Rome Statute of the International Criminal Court, opened for signature 17 July 1998, 2187 UNTS 90 (entered into force 1 July 2002).

2 G P Fletcher, The Grammar of Criminal Law-American, Comparative, and International, Volume I: Foundations (2007) 46.

${ }^{3}$ In similar vein, Professor Ambos argues that it may be 'necessary for judging a person's criminal responsibility in a just and fair manner' to take the distinction into account, see K Ambos, Treatise on International Criminal Law-Volume I: Foundations and General Part (2013) 306-307; K Ambos, 'Defences in international criminal law' in B S Brown (ed), Research Handbook on International Criminal Law (2011) 301.
} 
In the following, this article will first explain why classification and taxonomy are important in international criminal law (as indeed they are in criminal law generally). It will then examine the different defences listed in Art. 31 (1) and compare them in turn to civil and common law positions. The aim is to assess the extent to which the individual 'grounds of excluding criminal responsibility' can be categorized according to the concepts of 'bar to responsibility', 'justification' and 'excuse' as recognized, in particular, by German criminal law, and in how far they follow the broad 'one-size-fits-all' notion of common law defences, here exemplified by English criminal law. This is done with full awareness that German law cannot be taken to represent all civilian legal systems, just as English law can no longer be said to represent 'the' common law. These jurisdictions are used as examples, and the reader should be aware of this throughout this paper. ${ }^{4}$

\section{Why classifying 'defences' matters in international criminal law}

In domestic legal systems, exclusion grounds come in different guises. They may amount to affirmative objections which, once it has been established that the relevant conduct meets the offence definition, seek nonetheless to avoid liability by reference to exceptional circumstances. Or they may be framed in negative terms, forming part of the offence definition, so that, if raised successfully, not even the offence definition is satisfied.

In the common law world, the terminology for exculpatory claims is rather non-specific: at its broadest, we say 'defences' when meaning any ground, whether substantive or procedural, which a defendant may raise in order to avoid liability. More specifically, we may use the term to designate those defensive claims of substantive criminal law that, whilst offering a reason for acquittal, concede the commission of the offence in question. ${ }^{5}$

In civil law countries, by contrast, one finds further, and more subtle, distinctions, such as between substantive 'defences' which offer an excuse and

\footnotetext{
${ }^{4}$ There have been some statutory changes to English criminal law since the Rome Statute was enacted. These are ignored in this article, given that they could not have been in the mind of the drafters. However, more recent cases which serve to clarify the substance of the underlying common law position are taken into account and referred to as required.

5 J Gardner, 'Fletcher on Offences and Defences' in Offences and Defences-Selected Essays in the Philosophy of Criminal Law (2007) 141.
} 
those which serve to justify. ${ }^{6}$ The difference is one between defensive claims which reverse the wrongfulness of one's conduct (justification) and those which merely negate the blameworthiness of one's actions (excuse). ${ }^{7}$ While it has been suggested that such a distinction is of no practical relevance in the context of international criminal law, ${ }^{8}$ the force of this assertion appears doubtful. It is true that the drafters of the Rome Statute consciously chose 'neutral' terminology which avoids the language of either excuse or justification, ${ }^{9}$ so as not to appear to favour one rather than the other legal tradition. It is also true that both justifications and excuses lead to an acquittal, a fact from which one could possibly conclude that the distinction hardly matters in practice. However, there are at least four good reasons for international criminal law to distinguish between 'defences' that exclude the accused's legal responsibility because of an incapacity to act autonomously (bar to responsibility), those that challenge the wrongfulness of his act (justification) and those that negate the blameworthiness of his wrongdoing where his capacity to act autonomously remains intact (excuse): first, if we accept (with the civilian tradition) that conduct which is excused, but not justified, remains wrongful, ${ }^{10}$ such conduct could be lawfully resisted and be subject to self-defence. ${ }^{11}$ As the Rome Statute recognizes self-defence (Art. 31 (c)), the distinction could matter if an accused sought to rely on self-defence in relation to another's conduct which may be excusable but not justifiable. Secondly, the distinction could have consequences for the liability of accomplices: one can only be an accomplice to wrongful conduct, as it is permissible to support lawful activities. Thus, someone may legitimately assist another with conduct that is justified (and hence lawful), but not with conduct which is merely excused. ${ }^{12}$ As the Rome Statute in Art. 25 (3) also provides for rules on complicity, the distinction may become relevant in this context. Thirdly,

\footnotetext{
6 The old common law drew a similar distinction in the context of homicide, see J C Smith, Justification and Excuse in the Criminal Law (1989) 7-8. Since the 1970s, the distinction has (re)gained scholarly interest in the common law world, see e.g. G P Fletcher, Rethinking Criminal Law (1978) ch 10; KJ M Smith, A Modern Treatise on the Law of Criminal Complicity (1991) 120-124. See also $\$ 1.02$ (1) (a) of the Model Penal Code (MPC).

7 Fletcher, Rethinking Criminal Law, above n 6, 577.

8 M Scaliotti, 'Defences Before the International Criminal Court: Substantive Grounds for Excluding Criminal Responsibility - Part 1' (2001) 1 International Criminal Law Review 111, 118.

9 C K Hall, 'The Jurisdiction of the Permanent International Criminal Court over Violations of Humanitarian Law' in F Lattanzi (ed), The International Criminal Court-Comments on the Draft Statute (1998) 19, 46.

${ }^{10}$ Fletcher, Rethinking Criminal Law, above n 6, 759.

11 Ibid, at 760 .

${ }^{12}$ Ibid, at 761-762; KJ M Smith, above n 6, 121.
} 
the distinction has signal-effect in the sense of 'fair labelling.' ${ }^{13}$ Justifications and excuses tell us something about the quality of the defendant's act: justifications show that what the defendant did was actually lawful even though some harm may have been caused; ${ }^{14}$ excuses indicate that the defendant's conduct is still judged wrongful by the law, even though we are sympathetic to the defendant's plight and, for that reason, may exonerate him. ${ }^{15}$ A court, in turn, may be less reluctant to allow a defendant to rely on a defence if it is cognisant of the fact that recognition of the (excusatory) defence does not signify endorsement of the act. The refusal of the Yugoslavia Tribunal in Erdemovic ${ }^{16}$ to recognise duress as a defence to murder (albeit not in applying the Rome Statute) may well be symptomatic of a failure to appreciate the distinction in international criminal law. Finally, most people would accept that there is no guilt - in the moral sense - if the accused at the relevant time was incapable of acting in a rule-conformant way. This is what the civilian idea of a 'bar to responsibility' is all about: such a defence entails that while the condemned act may have been both wrongful and blameworthy, the actor cannot be held responsible for it. Such a defence amounts to a statement about the 'quality' of the actor rather than that of the act, and its nature may go some way towards explaining why the Rome Statute allows for some defences (such as insanity) to be raised concerning crimes (such as genocide) which seem inexcusable. ${ }^{17}$ For all these reasons, it is suggested that classifying 'defences' matters in international criminal law.

\section{Grounds for excluding criminal responsibility}

\subsection{Mental impairment (Art. 31 (1) (a), (b) Rome Statute)}

Nulla poena sine culpa. This principle embodies a value judgment that only the guilty should be criminally punished. The same principle lies behind those provisions that deal with mental impairment in all legal systems; yet it is implemented in very different ways in the common and civil law traditions and the Rome Statute respectively.

\footnotetext{
${ }^{13}$ See generally G Williams, 'Convictions and Fair Labelling' (1983) 42 CLJ 85-95; J Chalmers and F Leverick, 'Fair labelling in criminal law' (2008) 71 MLR 217-246.

${ }^{14}$ Scaliotti, above n 8, 112; Fletcher, Rethinking Criminal Law, above n 6, 761-762.

${ }^{15}$ Fletcher, Rethinking Criminal Law, above n 6, 459.

${ }^{16}$ ICTY (Appeals Chamber), Judgment of 7 October 1997.

${ }^{17}$ In similar vein, see J Horder, 'Criminal Law: Between Determinism, Liberalism and Criminal Justice’ (1996) 49 CLP 159, 166-167.
} 


\subsubsection{Mental disease or defect (Art. 31 (1) (a) Rome Statute)}

(a) In German law, 'a person is not criminally responsible if at the time of the act, because of a psychotic or similar serious mental disorder, or because of a profound interruption of consciousness or because of feeble-mindedness or any type of serious mental abnormality, he is incapable of understanding the wrongfulness of his conduct or of acting in accordance with this understanding' (\$20 StGB). This ground for excluding criminal responsibility is technically regarded as a 'bar to responsibility' (Schuldausschließungsgrund) rather than an 'excuse' (Entschuldigungsgrund). The law thus accepts that the alleged perpetrator was incapable of acting in a rule-conformant way (Unfähigkeit zu normgemäßem Handeln) at the relevant time because of a mental condition rather than some special circumstances. ${ }^{18}$ Accordingly, his act is not excused; rather, his mental impairment or illness is treated as a reason for denying his capacity to be held criminally accountable.

$\$ 20$ StGB offers a ground for excluding criminal responsibility to those affected by a 'serious mental disorder', 'feeble-mindedness', a 'profound interruption of consciousness' or any type of 'serious mental abnormality'. This is a high threshold. Where it is not met, a defendant may have resort to the provision in $\$$ $21 \mathrm{StGB}$ on diminished responsibility (verminderte Schuldfähigkeit). However, diminished responsibility is neither treated as 'barring responsibility' nor as an 'excusing' circumstance. $\$ 21$ StGB provides for a mere reduction in punishment. ${ }^{19}$ Diminished responsibility is thus treated only as a mitigating factor relevant to sentencing. For a defendant, it is more advantageous to bring himself within the boundaries of $\$ 20$ StGB: if the conditions therein are satisfied, he will be acquitted. ${ }^{20}$ Of course, there is a strong 'social defence' concern about allowing a (potentially) dangerous person to remain at large. The court is therefore able, in appropriate cases, to order his compulsory hospitalization or make an appropriate alternative order. ${ }^{21}$

\footnotetext{
${ }^{18}$ K Lackner and K Kühl, Strafgesetzbuch mit Erläuterungen (StGB), (27th edn, 2011) $\$ 20$ [12]; W Perron in A Schönke and H Schröder (eds), Strafgesetzbuch: Kommentar (StGB) (28th edn, 2010) $\$ 20$ [5]; R Eschelbach in B von Heintschel-Heinegg (ed), Beck'scher Online Kommentar (BeckOK StGB) (Updated: 8. 3. 2013) $\$ 20$ [3].

${ }^{19} \$ 49$ StGB sets out the applicable reduced punishment scales.

${ }^{20} \mathrm{G}$ Freund, 'Materiell-rechtliche und prozessuale Facetten des gesamten StrafrechtssystemsGedanken aus Anlass des “Marburger Strafrechtsgesprächs 2004”' (2005) 321-338 Goltdammer's Archiv für Strafrecht 322.

${ }^{21}$ See the StGB's provisions on Massregeln der Besserung und Sicherung (improvement and protection orders): $\$ 63 \mathrm{StGB}-$ Unterbringung in einem psychiatrischen Krankenhaus (institutionalisation
} 
(b) In English law, the area of mental impairment is governed by two separate 'defences': the 'M'Naghten Rules' on insanity ${ }^{22}$ and 'diminished responsibility. ${ }^{23}$ While the former apply to any offence, the latter operates as a special partial defence ${ }^{24}$ to murder only, reducing the accused's liability to manslaughter. Diminished responsibility (which until October 2010 required a substantial impairment of mental responsibility and since then requires a substantial impairment of the defendant's ability to (1) understand the nature of his conduct, (2) to form a rational judgment, or (3) to exercise self-control) is a matter of degree, while insanity amounts to an 'all-or-nothing' defence: either the defendant is able to demonstrate that he was legally insane when he committed the crime or he was not. Whether the 'M'Naghten Rules' on insanity are best seen as an excuse ${ }^{25}$ or some kind of 'status defence' by which the defendant denies legal responsibility from the outset and which automatically brings with it an exemption from punishment ${ }^{26}$ remains subject to debate. ${ }^{27}$ This issue is not without practical sig-

in a mental hospital); $\$ 64$ StGB-Unterbringung in einer Entziehungsanstalt (hospitalization for withdrawal treatment); $\$ 66$ StGB-Unterbringung in der Sicherungsverwahrung (preventative incarceration); $\$ 69$ StGB-Entziehung der Fahrerlaubnis (revocation of driving licence); $\$ 70 \mathrm{StGB}-$ Anordnung des Berufsverbotes (prohibition to carry out a certain occupation).

${ }^{22}$ M'Naghten's Case 184310 C \& F.

${ }^{23}$ S. 2 of the Homicide Act 1957. Prior to October 2010 this read: 'Where a person kills or is a party to the killing of another, he shall not be convicted of murder if he was suffering from such abnormality of mind (whether arising from a condition of arrested or retarded development of mind or any inherent causes or induced by disease or injury) as substantially impaired his mental responsibility for his acts and omissions in doing or being party to the killing'. In October 2010, the Coroners and Justice Act 2009, s. 52(1), amended s. 2 of the 1957 Act, so that it now reads: 'A person ("D") who kills or is a party to the killing of another is not to be convicted of murder if $\mathrm{D}$ was suffering from an abnormality of mental functioning which arose from a recognised medical condition, substantially impaired D's ability to [understand the nature of D's conduct; to form a rational judgment; to exercise self-control] and provides an explanation for D's acts and omissions in doing or being a party to the killing'.

${ }^{24}$ Partial defences are a category in between ordinary defences which exonerate completely and mitigating factors which make no difference to criminal liability but can be taken into account for sentencing purposes. They serve to reduce the harshness of the mandatory life sentence which follows a murder conviction.

${ }^{25}$ See J C Smith, above n 6, 11; Fletcher, Rethinking Criminal Law, above n 6, 798-799; KJ M Smith and W Wilson, 'Impaired Voluntariness and Criminal Responsibility: Reworking Hart's Theory of Excuses-The English Judicial Response', (1993) OJLS 69, 81.

${ }^{26}$ Gardner, 'In Defence of Defences' in Offences and Defences, above n 5, 88; J Horder, Excusing Crime (2004) 102-103.

${ }^{27}$ See e.g. Fletcher, Rethinking Criminal Law, above n 6, 836-839; R D Mackay, Mental Condition Defences in the Criminal Law (1995) 81-90; KJ M Smith, above n 6, 118, 121. 
nificance due to the fact that many transitory illnesses (such as sleep-walking, ${ }^{28}$ epileptic episodes ${ }^{29}$ and hyperglycaemia ${ }^{30}$ ) have been held to fulfil the legal definition of a 'disease of the mind': however, calling someone who inflicts harm during a hyperglycaemic episode 'mentally diseased', thus denying his legal responsibility, does not seem entirely appropriate. If there is a hierarchy of defences, ${ }^{31}$ declaring someone incapable of bearing legal responsibility is less favourable than treating him as excused. ${ }^{32}$ Accordingly, raising insanity is often a means of last resort, and there is evidence that many defendants even prefer to plead guilty rather than risk a verdict of insanity. ${ }^{33}$ If insanity amounts to a 'status defence', then, at least as a matter of logic, the issue should be addressed at the beginning of the case rather than later. ${ }^{34}$ By contrast, if insanity is an excuse, the issue should come to bear on liability only after the wrongfulness of the relevant act has been established ${ }^{35}$ and other, more favourable defences have been rejected. This may be one reason why some commentators prefer to regard the 'M'Naghten Rules' as an excuse. On the other hand, compelling arguments have been made in favour of the exemption view, which point out the difference between defensive claims by which the defendant still asserts some rational competence by offering a comprehensible reason for his conduct (excuses) and defences where his denial of responsibility amounts to a denial of rational competence. ${ }^{36}$ The latter view seems more in line with the essence of the 'M'Naghten Rules'. These ask whether 'at the time of the committing of the act, the party accused was labouring under such a defect of reason, from disease of the mind, as not to know the nature and quality of the act he was doing; or, if he did know it, that he did not know he was doing what was wrong. ${ }^{37}$ The first alternative deals with the situation where insanity negatives mental elements in the definition of a particular offence; the second alternative concerns a lack of capacity for normative understanding. Notably,

\footnotetext{
${ }^{28} R v$ Burgess [1991] 2 QB 92.

${ }^{29} R v$ Sullivan [1984] AC 156.

${ }^{30} R v$ Hennessy (1989) 89 Cr App R 10.

${ }^{31}$ Gardner, 'In Defence of Defences' in Offences and Defences, above n 5, 87-89; Horder, Excusing Crime, above n 26, 99-103.

32 See Gardner, 'The Gist of Excuses' in Offences and Defences, above n 5, 134; Horder, Excusing Crime, above n 26, 103.

${ }^{33}$ Rv Hennessy (1989) 89 Cr App R 10; A Ashworth, Principles of Criminal Law (2009) 90; R D Mackay, 'Fact and Fiction about the Insanity Defence' (1990) Crim LR 247.

${ }^{34}$ Fletcher, Rethinking Criminal Law, above n 6, 836.

35 Ibid.

${ }^{36}$ Gardner, 'The Gist of Excuses' in Offences and Defences, above n 5, 131-134.

${ }^{37}$ Emphasis added.
} 
there is no mention of a lack of volitional control. Whether a particular condition amounts to a disease of the mind is not a medical but a legal question. The courts draw a distinction between 'internal' and 'external' factors affecting a defendant's mental condition. ${ }^{38}$ Only the former are regarded as a 'disease of the mind' on the assumption that they may recur and thus require the special verdict of 'not guilty by reason of insanity' (as opposed to a finding of automatism which leads to an acquittal). Again, 'social defence' concerns allow the courts to order a legally insane person to be institutionalized. ${ }^{39}$

(c) The 'mental incapacity' ground in Art. 31 (1) (a) comprises two requirements: first, a 'mental disease or defect' which, secondly, 'destroys [the] capacity to appreciate the unlawfulness or nature of [one's] conduct, or [the] capacity to control [one's] conduct to conform to the requirements of law'. There is not much practical difference between this provision and the English and German rules. However, the word 'capacity' is key. It is reminiscent of the German , i.e. the idea that the insane person is neither justified nor excused, but simply not capable of culpable conduct. If one considers the context in which trials of the ICC take place, the signalling effect of this wording cannot be overestimated: the accused's acquittal is not a judgment about the act itself, but about the accused's capacity, at the time of the relevant conduct, to take responsibility for it. This is reinforced by the fact that Art. 31 (1) (a) takes account of impairments on the volitional level: the destruction of the capacity 'to control [one's] conduct' may also lead to the exclusion of criminal responsibility. The Rome Statute thus reflects the broader German approach which takes on board the idea of an incapacity to act in a rule-conformant way. This is in contrast to the 'M'Naghten Rules' that speak solely in terms of a 'defect of reason', thereby focusing on the accused's cognitive abilities.

Neither the Rome Statute nor the Rules of Procedure and Evidence foresee detention as a consequence of a successful plea under Art. 31 (1) (a). However, if the defendant suffered from a mental condition that is likely to recur, and there is a danger that he may commit further atrocities after his acquittal, it could be argued that the domestic authorities or, indeed, the Netherlands as the

\footnotetext{
${ }^{38}$ See e.g. $R v$ Quick [1973] QB 910, 922.

${ }^{39}$ Until the enactment of the Criminal Procedure (Insanity and Unfitness to Plead) Act 1991, the result of a successful defence of insanity was mandatory and indefinite commitment to mental hospital. The 1991 Act grants courts in such cases a discretion to choose committal to hospital, absolute discharge, a guardianship order, or a supervision order, see Ashworth, above n 33, 90 and 142 .
} 
ICC's host country ${ }^{40}$ will have a strong incentive to keep him off their streets. Professor Ambos has suggested that the uncertain consequences of a successful plea, coupled with the practical difficulties of adducing reliable medical evidence many years after the fact, may explain why defendants are reluctant to invoke this defence before the ICC. ${ }^{41}$ This seems plausible and would conform with research done in the domestic context which has found insanity to be an unpopular defence, ${ }^{42}$ for the above reasons as well as the stigma attached to being labelled 'insane." ${ }^{43}$

\subsubsection{Intoxication (Art. 31 (1) (b) Rome Statute)}

While insanity is rarely the fault of the individual, intoxication usually is. Although most legal systems (leaving aside those belonging to the Islamic legal tradition) recognize that the drunken defendant may be under an impairment which bears upon his culpability, his conduct is usually condemned in one way or another; the victims deserve that the drunken defendant be held to account, his conviction signals this to the victims, the perpetrator and the world. In addition, social defence concerns mean that he will not usually be allowed to walk free, particularly where the court is not convinced that the act in question was a 'one-off'.

(a) $\$ 20$ StGB does not explicitly mention intoxication as a ground for excluding culpability. However, the dominant view among judges and scholars holds that a 'psychotic or similar serious mental disorder' can be caused by (very severe) intoxication, and on that basis criminal responsibility may be excluded in individual cases. The test is the same as for insanity. It is irrelevant for purposes of $₫ 20$ StGB whether the intoxication is voluntary or involuntary. $\$ 20$ StGB thus follows the logic of the maxim nulla poena sine culpa in recognizing that an intoxicated person may lack the legal capacity to commit the crime he is accused of. Social defence and signalling concerns, however, are addressed by the separate offence of 'causing harm while voluntarily intoxicated' in $\$ 323$ a (Rauschtat). This offence puts under sanction voluntary, i.e. intentional or careless, intoxication which results in the commission of a crime. $\$ 323$ a StGB penalizes that the

\footnotetext{
${ }^{40}$ Ambos, Treatise, above n 3, 323 .

${ }^{41}$ Ibid, 323-324.

${ }^{42}$ Ashworth, above n 33, 90; D Ormerod, Smith and Hogan's Criminal Law (13 ${ }^{\text {th }}$ edn, 2011) 294; R D Mackay, 'Fact and Fiction About the Insanity Defence' [1990] Crim LR 247; R D Mackay and G Kearns, 'The Continued Underuse of Unfitness to Plead and the Insanity Defence' [1994] Crim LR 546; R D Mackay and G. Kearns, 'More Fact(s) about the Insanity Defence' [1999] Crim LR 714.

${ }^{43}$ Ormerod, above n 42, 294-295.
} 
defendant has at least carelessly put himself in the intoxicated state which then excludes his culpability, in circumstances were he should have foreseen that there was a possibility that he would commit a crime once intoxicated. This latter requirement, which corresponds to Art. 31 (1) (b) Rome Statute, is not contained in the text of the provision. Once it was thought that becoming totally intoxicated was by itself wrongful, so that the likelihood of a criminal act need not have been foreseeable. ${ }^{44}$ This was heavily criticized, and the Grand Senate of the Bundesgerichtshof (BGH) later thought that the rule was difficult to reconcile with the general principle that people can only be held accountable for acts they intended or at least should have been able to foresee. ${ }^{45}$ As such, $₫ 323$ a StGB is a compromise that attempts to accommodate competing policy concerns: on the one hand, it seems only just that a person who gets drunk and commits a crime while intoxicated should be liable for the consequences; on the other hand, the legal order generally abides by the principle that liability and punishment should be proportional to the culpability of the perpetrator. The latter concern is taken into account insofar as this provision only penalizes negligence as to the risk of committing a crime whilst intoxicated. ${ }^{46}$

However, $\$ 323$ a StGB will not be used where the accused can be held liable for the actual crime according to the principles of actio libera in causa. These apply in circumstances where, at the time of getting intoxicated, he had already formed the intent to commit the crime or should, at least, have foreseen that he was likely to commit the crime. ${ }^{47}$

(b) The common law does not treat intoxication as a defence in the technical sense. Instead, it is commonly dealt with under the heading of mens rea which it is said to negate in certain circumstances. ${ }^{48}$ Thus, the Law Commission in their recent Report on Intoxication and Criminal Liability write: ${ }^{49}$

There is no common law or statutory "defence of intoxication". [...] However, if D's state of intoxication was such that D did not act with

\footnotetext{
${ }^{44}$ Bundesgerichtshof (BGH) [Federal Court of Justice], Judgment of 12 April 1951, BGHSt 1, 124 (125-126); BGH, Judgment of 2 May 1961, BGHSt 16, 124 (125).

${ }^{45}$ BGH, judgment of 15 October 1956, BGHSt 9, 390 (396-397); likewise: BGH, Judgment of 7 May 1957, BGHSt 10, 247 (250).

${ }^{46}$ D Sternberg-Lieben and B Hecker in Schönke and Schröder, above n 18, $\$ 323$ a [9].

${ }^{47}$ Lackner and Kühl, above n 18, \$323 a [19]; J Dallmeyer in BeckOK StGB, above n 18, \$323 a [18].

${ }^{48}$ For an understanding of the intoxication doctrine's function as inculpating rather than exculpating the defendant see A P Simester, 'Intoxication is never a Defence' (2009) Crim LR 3.

${ }^{49}$ The Law Commission, Intoxication and Criminal Liability, 2009, Report No 314, Cm 7526 [1.15-1.16].
} 
the subjective fault (culpable state of mind) required for liability by the definition of the offence it may be possible for D to secure an acquittal for that reason.

The doctrine is not acknowledged as a defence for policy arguments of social defence: we cannot simply acquit all 'those who cause harm and who lack awareness at the time because of intoxication.' 50 The current English approach, developed in DPP v Majewski, ${ }^{51}$ is rather piece-meal. Where the offence is a crime of 'specific intent,', intoxication may amount to a 'defence' if it is sufficient to negative mens rea. It cannot, however, be a 'defence' for crimes that require merely 'basic intent. ${ }^{53}$ The reason seems to be that there are few offences of specific intent, and these are usually underpinned by a lesser offence of 'basic intent', so that no great loss of social defence occurs: ${ }^{54}$ the offence is merely reduced to the lesser offence. The Majewski rule applies to 'voluntary' intoxication; where it is 'involuntary' as, for example, where the accused's drink has secretly been spiked by a third party, the accused is given a complete defence, but only where the intoxication totally negatived his mens rea (so that he had no idea what he was doing). ${ }^{55}$

The English equivalent of the German actio libera in causa can be found in the case of Attorney General of Northern Ireland $v$ Gallagher. ${ }^{56}$ D gets drunk to give himself 'Dutch courage' to commit an offence he is already contemplating. ${ }^{57}$ As in German law, he has no defence.

(c) Art. 31 (1) (b) provides for a separate and independent exclusion ground of intoxication. This seems wise, as in drawing a clear distinction between mental

\footnotetext{
${ }^{50}$ Ashworth, above n 33, 197.

${ }^{51}$ [1977] AC 443.

${ }^{52}$ The distinction seems to be based on policy rather than principle. As a rule of thumb, crimes of recklessness, negligence and strict liability are treated as basic intent crimes, whereas those requiring intent, knowledge or dishonesty are usually regarded as crimes of specific intent. This 'simple practical approach' (Ormerod, above n 42,318) has recently been cast into doubt, albeit through obiter dicta, by the Court of Appeal in Heard [2007] EWCA Crim 125).

${ }^{53}$ Ormerod, above n 42, 314; B Foley, 'Same Problem, Same Solution? The Treatment of the Voluntarily Intoxicated Offender in England and Germany' (2001) Trinity College Law Review 119, 122.

${ }^{54}$ Ashworth, above n 33, 198.

${ }^{55} R v$ Kingston [1995] 2 AC 355.

${ }^{56}$ [1963] AC 349.

${ }^{57}$ The principle in Majewski to the effect that voluntary intoxication is no defence to a charge of a crime of basic intent even if it did cause the defendant to lack mens rea might also be premised on ideas of prior fault, see Ormerod, above n 42, 315-316.
} 
disease or defect, on the one hand, and intoxication on the other, the Rome Statute draws attention to the fact that while the former is generally and explicitly recognized as a ground for excluding responsibility both in the common law and civil law traditions, the latter is not. On the other hand, it seems debatable whether the Rome Statute should recognize such a controversial 'defence' at all: as one commentator has pointed out, the crimes the ICC is concerned with are of 'such indefeasible dimensions that any attempts to justify or excuse them appear obscene. ${ }^{58}$ These concerns are, however, alleviated by the fact that the threshold for this 'defence' is high: the practical result of the German and English rules is that a person who kills in a state of intoxication, in circumstances in which he can be said to be negligent as to the risk that he might commit a crime, will probably end up serving no more than five years in prison (Germany) or be guilty of manslaughter rather than murder (England, avoiding the mandatory life sentence). The Rome Statute is not as forgiving: such a person would have no defence at all. ${ }^{59}$

Officially the provision is neither categorized as an 'excuse' nor as a 'bar to responsibility'. It is, however, suggested that there are good reasons for treating it as the latter: 'excuses' acknowledge that there are situations in which people may have little choice but to engage in harmful and unjust conduct. ${ }^{60}$ We are sympathetic towards their behaviour because we can understand their plight. Where voluntary intoxication leads to criminal conduct, however, the domestic law clearly shows that we are not very sympathetic, and even less so where the crime was premeditated and the intoxication caused intentionally, so as to 'steal oneself away' from the legal consequences. This explains why neither German nor English law treats these cases as 'excused'. Instead, premeditated crimes committed whilst being intoxicated are seen as culpable and punishable. The same is true for careless conduct (cf. $\$ 323$ a StBG; and the English doctrine of 'specific intent'). Only the most extreme cases of intoxication are subject to the legal consequences of $\$ 20$ StGB, and in these instances, rather than excusing the perpetrator, German law recognizes that the actor did not realize that he was committing a wrong, that he lacked the capacity to act as a truly autonomous person-thus his actions cannot be attributed to him in the legal sense. It is suggested that Art. 31 (1) (b) adheres to the same idea. Intoxication has yet to

\footnotetext{
${ }^{58}$ A Eser in O Triffterer (ed), Commentary on the Rome Statute of the International Criminal Court: Observers' Notes, Article by Article (2008), Art. 31 [12].

${ }^{59} \mathrm{~K}$ Ambos, 'Zur Rechtsgrundlage des Internationalen Strafgerichtshofs-Eine Analyse des RomStatuts', 111 Zeitschrift für die gesamte Strafrechtswissenschaft (ZStW) 189, 199.

${ }^{60}$ G P Fletcher, Basic Concepts of Criminal Law (1998) 131.
} 
play a significant role before the ICC; that it has not to date may be due to its restricted ambit, ${ }^{61}$ as well as to difficulties in furnishing reliable evidence. ${ }^{62}$

\subsection{Self-defence (Art. 31 (1) (c) Rome Statute)}

Recht braucht Unrecht nicht zu weichen. ${ }^{63}$ Hart puts it this way: 'Killing in self-defence is an exception to a general rule making killing punishable; it is admitted because the policy or aims which in general justify the punishment of killing [...] do not include cases such as this' ${ }^{64}$ While this explanation has been criticized, all commentators are at one in acknowledging the existence of a right to self-defence. ${ }^{65}$ It is, moreover, generally accepted that an imminent unlawful attack against a protected interest (e.g. life, bodily integrity, and property), a proportional reaction and the defender's intention of acting in self-defence will usually be required, be it in common law or civil law jurisdictions. ${ }^{66}$ However, as Fletcher and Ohlin argue, 'the elements of the law take on different connotations depending on the underlying philosophical conception of self-defense'. ${ }^{67}$ The examples of mistaken and excessive self-defence demonstrate the different approaches quite well.

(a) The civil law prefers a unified concept of self-defence and defence of others, as illustrated by the German $₫ 32$ StGB (Notwehr). $\$ 32$ StGB is seen as a justification rather than an excuse. ${ }^{68}$ Cases of excessive self-defence, by contrast, are treated as excusing only (cf. $\$ 33$ StGB Überschreitung der Notwehr). $\$ 33$ StGB applies where the defender uses excessive force to ward off an unlawful attack

\footnotetext{
${ }^{61}$ It cannot be invoked if 'the person has become voluntarily intoxicated under such circumstances that the person knew, or disregarded the risk, that, as a result of the intoxication, he or she was likely to engage in conduct constituting a crime within the jurisdiction of the Court'.

${ }^{62}$ Ambos, Treatise, above n 3, 328, 330.

63 'Right need never yield to wrong' (as translated by Fletcher, Rethinking Criminal Law, above n 6, 865). On the German expression see e.g. Reichsgericht (RG) [Court of the German Empire], Judgment of 20 September 1920, 55; RGSt 55, 82 (85). Note that today this holds true in a restricted sense only: in contrast to the opinion of the Reichsgericht, it is now generally acknowledged that self-defence is limited by the notion of proportionality (Verhältnismäßigkeitsgrundsatz).

${ }^{64} \mathrm{H}$ L A Hart, Punishment and Responsibility: Essays in the Philosophy of Law (2008) 13.

${ }^{65}$ See K Ambos, Treatise, above n 6, 330, 333 and C Gosnell in Cassese's International Criminal Law (2013) 211 n 6, both with reference to Prosecutor v Kordic and Cerkez, No IT-95-14/2-T, Trial Chamber Judgment, para 451 (26 February 2001).

${ }^{66}$ Ambos, Treatise, above $\mathrm{n} 3,334$. See also $\$ 32$ StGB.

${ }^{67}$ G P Fletcher and J D Ohlin, Defending Humanity: When Force is Justified and Why (2008) 55.

${ }^{68}$ See C Momsen in BeckOK StGB, above n 18, § 32 [8].
} 
because of confusion, fear or terror. The law allows for an excuse under these narrow boundaries because people are generally sympathetic to a person who overreacts for one of these reasons.

Mistaken self-defence is also excusable under German law. ${ }^{69}$ It is established if the defender erroneously believes that he is being attacked. In these circumstances, the law assumes that the defender is operating under a certain kind of mistake called Erlaubnistatbestandsirrtum (mistake of circumstantial fact) ${ }^{70}$ which negates his culpability: ${ }^{71}$ while he deliberately fulfils the requirements of an offence, he believes that the factual circumstances justify his conduct. This leads him to act intentionally-he wants to use force to fend off the (imagined) attackbut blamelessly. He remains liable, however, for negligence (where the particular offence is underpinned by a lesser offence which lets a mental element of negligence suffice). ${ }^{72}$

(b) In contrast to German law, the common law treats mistaken self-defence the same as self-defence. ${ }^{73}$ Accordingly, mistaken self-defence is often regarded as justified ${ }^{74}$ rather than excused. $^{75}$ This is problematic, however, for if we treat acts of self-defence which are based on a mistake (of circumstantial fact) as justified, then the person against whom the person operating under a mistake 'defends' himself would, if one followed this through to its logical conclusion, be required to tolerate the defensive conduct: where the law regards putative self-defence as justified and hence as lawful, such conduct may not be resisted. This result is counter-intuitive, however, especially since we are dealing here with an innocent party: the person against whom putative self-defence is being exercised has done nothing wrong; far from being an attacker, his conduct is

\footnotetext{
${ }^{69}$ M Heuchemer in BeckOK StGB, above n 18, $\$ 33$ [1].

${ }^{70}$ As opposed to a mistake of normative evaluation (which occurs, for example, where a householder kills a burglar in the belief that it is legal to kill burglars caught in the act). If such a mistake was unavoidable, the perpetrator will not be punished (see $\$ 17 \mathrm{StGB}$ ). If the mistake was avoidable, his punishment may be reduced according to $\$ 49$ (1) StGB.

71 This is a somewhat simplified account of the consequences of an Erlaubnistatbestandsirrtum. In fact, there is an academic dispute about what element exactly within the tripartite structure of offences is affected by such a mistake. Most commentators assume that it negates the so-called Vorsatzschuldvorwurf (culpability relating to the actor's intention).

${ }^{72}$ W Perron in Schönke and Schröder, above n 18, $\$ 33$ [1].

${ }^{73}$ In English law, common law self-defence has recently been given some statutory backing by s. 76 of the Criminal Justice and Immigration Act 2008.

${ }^{74}$ See $\$ 3.04$ Model Penal Code (MPC); The Law Commission, Murder, Manslaughter and Infanticide, Project 6 of the Ninth Programme of Law Reform: Homicide, (2006), Law Com No. 304, [5.51]. See also the criticism in Fletcher, Rethinking Criminal Law, above n 6, $762 \mathrm{ff}$.

${ }^{75}$ F Leverick, Killing in Self-Defence (2006) 165; J C Smith, above n 6, 10.
} 
lawful and blameless. It is only because of a mistake that the other party sees a need to defend himself, and at worst, the putative self-defender's mistake in imagining the attack was unreasonable, so that he can actually be blamed for his reaction. The better view, therefore, is to regard mistaken self-defence at common law as unjustified, but excusable, conduct.

English law is particularly generous towards mistaken self-defenders, for even where the defendant makes an unreasonable mistake about being attacked, as long as he honestly believed this was the case, he is entitled to an acquittal on the basis of self-defence (assuming that the other conditions of the defence-such as the use of objectively reasonable force in order to fend off the imagined attackare made out). ${ }^{76}$ In $R v$ Williams (Gladstone), ${ }^{77}$ the Court of Appeal confirmed that a defendant charged with assault could successfully plead self-defence on the basis of an honest but unreasonable belief. The defendant (D) observed V knock a youth to the ground. V claimed to be arresting the youth for mugging, but he failed to prove this when asked to do so. D, believing the youth was being unlawfully assaulted by $\mathrm{V}$, punched $\mathrm{V}$ in the face. It was held that the law looks to the defendant's subjective view of the circumstances as he honestly, even if mistakenly and unreasonably, believed them to be. ${ }^{78}$

The degree of force used, however, needs to be objectively reasonable. ${ }^{79}$ According to s. 76 (6) of the Criminal Justice and Immigration Act 2008, 'the degree of force used by $\mathrm{D}$ is not to be regarded as having been reasonable in the circumstances as D believed them to be if it was disproportionate in those circumstances'. Thus, if the force used was in fact excessive, the defence will fail. In that respect, English law may arrive at rather harsh results, in particular where the defensive act results in the death of the presumed attacker: in that event, as there is unlikely to be another defence available, the 'self-defender' will be convicted of murder. ${ }^{80}$ As the Law Commission has pointed out, 'there is no

\footnotetext{
${ }^{76}$ See s. 76 (4) (b) of the Criminal Justice and Immigration Act 2008 ('if D claims to have held a particular belief as regards the existence of any circumstances, [and] if it is determined that D did genuinely hold it, D is entitled to rely on it for the purposes of subsection (3), whether or not (i) it was mistaken, or (ii) (if it was mistaken) the mistake was a reasonable one to have made').

77 (1984) 78 Cr App R 276.

${ }^{78}$ Of course, as s 76 (4) (a) of the Criminal Justice and Immigration Act 2008 clarifies, if the defendant's mistake was an unreasonable one, this may be a reason for the jury to conclude that the belief was not, in fact, honestly held.

${ }^{79}$ S. 76 of the Criminal Justice and Immigration Act 2008.

${ }^{80} R v$ Clegg [1995] 1 AC 482 (determining that a soldier or police officer who, in the course of his duty, kills a person by the use of unreasonable force in self-defence is guilty of murder, not manslaughter).
} 
legal 'halfway house' for those who over-react, even when they are facing a threat of serious violence. ${ }^{81}$

(c) Art. 31 (1) (c) recognizes proportionate self-defence and defence of others against an imminent and unlawful use of force which entails danger for a person ${ }^{82}$ or for property of particular importance. ${ }^{83}$ It thus contains the classic elements of self-defence as a justification. This is reinforced by the fact that the question of whether the requirement of an imminent and unlawful use of force need exist objectively or whether it would suffice that the actor reasonably or honestly believed that it existed in order to be justified under the rubric of 'self-defence' was resolved in favour of the civil law approach. In other words, the reasonable or honest belief approach, as employed in the common law world, was rejected. ${ }^{84}$ Therefore, a person who is not actually attacked or endangered but believes this to be the case, is not justified under the Rome Statute's provision on self-defence (but may have resort to the rules on mistake of fact or law under Art. 32 ). ${ }^{85}$ It is suggested that this is the correct approach as it acknowledges that there is a difference between reality as it is and reality as it is perceived. The approach of English law tends to ignore this distinction and the drafters of the Statute were well-advised not to follow this approach. Take the example of killing in self-defence which may be justified under the requirements of Art. 31 (1) (c). Compare it to killing in mistaken self-defence. In the latter case, there is no aggressor. The perceived 'aggressor', however, possesses a right to life which he has not forfeited or put in danger by becoming an unlawful and imminent threat to the life of another. Instead of killing someone who was threatening someone else's right to life, a human being was killed in perceived self-defence who was posing no threat at all to anybody. Allowing a reasonable belief to justify (rather than excuse) the killing according to Art. 31 in the latter instance would have failed to provide an adequate protection for the right to life of the person who

\footnotetext{
${ }^{81}$ The Law Commission, A New Homicide Act for England and Wales? (2005) Consultation Paper No $177,[1.68]$.

${ }^{82}$ It is controversial whether 'person' attracts a narrow reading, so as to protect only a person's life and limb (see Cassese's International Criminal Law, above $\mathrm{n} 65,212$ ) or is to be understood more broadly, encompassing a person's liberty (Ambos, Treatise, above n 3, 340).

${ }^{83}$ Property is only protected 'in the case of war crimes' and insofar as it is 'essential for the survival of a person' or 'essential for accomplishing a military mission'. The property defence goes beyond the position in customary international law, see Cassese's International Criminal Law, above n 65, 212-213.

${ }^{84}$ K. Ambos, 'Other Grounds for Excluding Criminal Responsibility' in A Cassese et al (eds), The Rome Statute of the International Criminal Court: A Commentary, Vol. I (2002) 1032.

${ }^{85}$ Eser, above n 58, [45].
} 
was mistakenly believed to be an attacker. By excluding this and like cases, Art. 31 (1) (c) sends a clear signal that it is indeed intended as a justification rather than an excuse.

The Rome Statute does not explicitly address the problem of excessive self-defence which, as seen, is treated by German law as an excuse rather than a justification. Arguably, however, such cases may be dealt with via Art. 31(2) which empowers the ICC to 'determine the applicability' of the exclusionary grounds 'to the case before it. ${ }^{86}$

\subsection{Duress (Art. 31 (1) (d) Rome Statute)}

Art. 31 (1) (d) is framed in terms of 'duress', but it appears to blend requirements of duress with elements more typically associated with necessity. In this respect, the provision is reminiscent of the common law approach which, as we will see, tends to conflate the two concepts to some extent. ${ }^{87}$ This may reflect an underlying view that fair labelling is not as important in the classification of defences as it is in the classification of offences. Professor Clarkson, writing on the English law, has suggested that self-defence, necessity and duress could, without losing much, be unified under the heading of a single defence of 'necessary action'; he argues that the principle of fair labelling is of little relevance in the context of defences. ${ }^{88}$ However, as pointed out above, there are signalling concerns which point in favour of differentiation: surely it is better for a defendant to be acquitted on the basis that he did what anyone would and should have done (necessity) than on the basis that he gave in to pressure so that his conduct can be understood though not condoned (duress). The nature of a defence by reason of which a defendant is acquitted reflects on his attitude towards the law and may thus well influence the manner in which he is regarded by the public. In this sense, there is a hierarchy of defences; some reflect more favourably on the defendant than others. $^{89}$

German law, as we saw above, takes fair labelling seriously. It is fundamental to its structure of exculpatory and justificatory defences, with the result that,

\footnotetext{
${ }^{86} \mathrm{Ibid},[65]$.

${ }^{87}$ See e.g. W Wilson, Criminal Law (2008) 278. For an exception see: J Horder, 'Self-Defence, Necessity and Duress: Understanding the Relationship' (1998) 11 Canadian Journal of Law and Jurisprudence 143.

${ }^{88}$ C M V Clarkson, 'Necessary Action: a New Defence' (2004) Crim LR 81, 94.

${ }^{89}$ M Baron, 'Justifications and Excuses' (2005) 2 Ohio State Journal of Criminal Law 387, 389; Gardner, 'In Defence of Defences' in Offences and Defences, above n 5, 87-89; Horder, above n 26, 99-103.
} 
while English law uses the terms 'duress' and 'necessity' interchangeably at times, German law explicitly provides for a justificatory and an excusatory version of its pressure-related defence ('Notstand'). The Rome Statute, in an apparent concession to the common law, does not appear to draw this distinction by seemingly intermingling justificatory and excusatory elements. ${ }^{90}$ It will be argued in this article, however, that mixing up justification and excuse does not sit well with the structure of Art. 31 (1). It is suggested that a possible (and preferable) interpretation of Art. 31 (1) (d) is that it relates to (excusatory) duress only, which leaves a (justificatory) necessity defence to be subsumed under Art. 31 (3). This would align the Rome Statute with the German approach which will now be considered.

(a) The German Penal Code contains two provisions dealing with situations of necessity and duress: one provision is headed 'justificatory necessity' (Rechtfertigender Notstand), the other 'excusing necessity' (Entschuldigender Notstand). $₫$ 34 StGB deals with justificatory necessity. The provision states:

Whoever, faced with an imminent danger to life, limb, freedom, honour, property or any other legal interest which cannot otherwise be averted, commits an act to avert the danger from himself or another, does not act unlawfully, if, upon weighing the conflicting interests, in particular the affected legal interests and the degree of danger threatening them, the protected interest substantially outweighs the one interfered with. This shall apply, however, only to the extent that the act is a proportionate means to avert the danger.

The provision does not differentiate between dangers that emanate from human conduct and other sources of danger. However, the provision primarily assumes significance in the latter context. This is because in cases of human conduct amounting to an attack on legally protected interests, the defendant must have resort to the provision on self-defence as it is lex specialis (abschliessende Sonderregelung) to $\$ 34$ StGB. ${ }^{91}$

Necessity as a justificatory concept can be distinguished from self-defence on the basis that the former legitimates the invasion of interests belonging to an innocent third party. ${ }^{92}$ Self-defence, by contrast, concerns an invasion of interests belonging to the attacker, and hence the culpable party. Because it affects the

\footnotetext{
${ }^{90}$ Ambos, Treatise, above n 3, 359.

${ }^{91}$ Perron in Schönke and Schröder, above n 18, § 34 [6] and [16].

${ }^{92}$ Fletcher, Basic Concepts, above n 60, 138.
} 
rights of an innocent third party, $₫ 34$ StGB requires a careful balancing of the conflicting interests (Rechtsgüter). The act done to avert the danger needs to be proportionate, i.e. it must be capable of averting the danger with certainty (Geeignetheit), must constitute the least intrusive means by which to achieve this goal (Erforderlichkeit), and must also be adequate (Angemessenheit), in the sense that the means used must not be out of proportion to the goal to be achieved. The legal interests listed as worthy of the law's protection are safeguarded only insofar as they are not defeated by a competing interest which the legal system regards as more significant under the particular circumstances. ${ }^{93}$ The order in which they are enumerated is indicative of their relative value, with 'life' at the top and 'any other legal interest' (e.g. possession) at the bottom of the list.

It should be noted that the provision does not apply where the interests on either side of the balance sheet consist of one or several human lives, the assumption being that human life is not measurable by a utilitarian approach: all lives are of equal value and worthy of the law's protection; as such, one human life cannot justifiably be balanced against another or, indeed, several others. ${ }^{94}$ Such a balancing is, however, possible where $\$ 35$ StGB applies. This provision deals with necessity as an excuse, and it is grounded in sympathy for the defendant who, because of the particular circumstances, cannot fairly be expected to abstain from committing the prohibited act. $\$ 35$ StGB provides that 'whoever, faced with an imminent danger to life, limb or freedom which cannot otherwise be averted, commits an unlawful act to avert the danger from himself, a relative or person close to him, acts without guilt'. If he acts mistakenly (Putativnotstand), he will only be subject to criminal sanction if his mistake was avoidable. The punishment imposed may be reduced according to $\$ 35$ (2) StGB.

Significantly, the provision only applies where the act done to avert the danger was unlawful (i.e. it does not fulfil the requirements of-and is thus not justified according to- $\$ 34 \mathrm{StGB}$ ). As such, the act remains subject to claims of self-defence. $^{95} \S 35$ StGB is notably limited to the protection of life, limb and freedom and requires a special relationship (either of kinship or affection) between the defendant and the party to be protected. Generally, an accused will be able to rely on $₫ 35$ StGB as an excuse unless he could be fairly expected to withstand the relevant danger (Zumutbarkeit), either because he is acting in a professional capacity which entails a duty to assume certain dangers and, if

\footnotetext{
${ }^{93}$ Perron in Schönke and Schröder, above n 18, § 34 [25].

${ }^{94}$ Ibid, [23].

${ }^{95}$ Lackner and Kühl, above n 18, § 35 [1].
} 
necessary, to self-sacrifice (berufsbezogene Gefahrtragungspflichten) or because he himself has caused the danger in the first place. ${ }^{96}$ In the latter case, there is no reason for the law to be compassionate.

(b) English law distinguishes between the defences of duress, duress of circumstances and necessity. ${ }^{97}$ The law in this area does not draw as neat a (theoretical) distinction as the German provisions: in fact, the case-law of necessity and duress (of circumstances) has developed in a way that frequently appears to draw upon ideas of both excuse and justification. ${ }^{98}$

Duress operates as a general defence which is applicable to all crimes (except murder, ${ }^{99}$ attempted murder ${ }^{100}$ and, possibly, some forms of treason ${ }^{101}$ and conspiracy $^{102}$ ). Its ambit is, however, rather restricted: it requires that the defendant be faced with (1) an imminent threat of death or serious injury ${ }^{103}$ (2) emanating from another person which is (3) aimed at persuading him to commit a particular offence. The threat must be extraneous to the defendant ${ }^{104}$ and be of a nature that a sober person of reasonable firmness sharing the characteristics of the defendant would not have resisted. ${ }^{105}$ Thus, duress will be a defence only if the accused could not be reasonably expected to withstand the threat. This is to say, the defence will only succeed where a person of ordinary courage and self-restraint might have done as the defendant did. ${ }^{106}$ The belief that a threat has been made and will be implemented must be based on reasonable

${ }^{96}$ Perron in Schönke and Schröder, above n 18, $\$ 35$ [13a]; Momsen in BeckOK StGB, above $\mathrm{n} 18, \S 35$ [15-16].

${ }^{97}$ It remains unclear whether 'duress of circumstances' and 'necessity' express the same idea or whether the two defences embody separate concepts, see e.g. the ambiguous statement by Woolf LJ in Conway [1989] QB 290, 297: "[D]uress is an example of necessity. Whether "duress of circumstances" is called "duress" or "necessity" does not matter. What is important is that, whatever it is called, it is subject to the same limitations as to "do this or else" species of duress.' [sic] The current edition of Smith and Hogan's Criminal Law distinguishes between duress by threats and duress of circumstances on the one hand and necessity on the other (see Ormerod, above $n 42,362-365$ ). While this suggests, first, that duress of threats and duress of circumstances can be aligned, and secondly, that necessity is a separate defence, the distinction remains blurred in English law as a result of the imprecise use of terminology in the relevant case law.

${ }^{98}$ See Ashworth, above n 33, 212.

${ }^{99} R v$ Howe [1987] AC 417.

${ }^{100} R v$ Gotts [1992] 2 AC 412.

${ }^{101}$ The Law Commission, Murder, Manslaughter and Infanticide, above n 74, [6.5].

${ }^{102} R v$ Abdul-Hussain (1999) Crim LR 570.

${ }^{103}$ Psychological harm alone is insufficient, see $R v$ Baker and Wilkins (1997) Crim LR 497.

${ }^{104} R v$ Brown [2003] EWCA Crim 2637.

${ }^{105} R v$ Bowen (1996) 2 Cr App R 157; see also R v Graham (1982) 74 Cr App R 235); Howe, above n 99.

${ }^{106}$ Graham ibid; Howe, above $\mathrm{n} 99$. 
grounds. ${ }^{107}$ However, the threat need not be aimed at the defendant himself; it is sufficient that it be made against anyone for whom the defendant reasonably regarded himself as being responsible. ${ }^{108}$ Duress does not require any balancing of interests, but will not be available where the threat is a consequence of the defendant's prior fault. ${ }^{109}$

In $R v Z,{ }^{110}$ Lord Bingham stated that duress operates as an excuse:

'[w]here duress is established, it does not ordinarily operate to negative any legal ingredient of the crime which the defendant has committed. Nor is it now regarded as justifying the conduct of the defendant, as has in the past been suggested [...] Duress is now properly to be regarded as a defence which, if established, excuses what would otherwise be criminal conduct.'

The case law has not always been this clear or explicit: ${ }^{111}$ in $R v$ Howe, ${ }^{112}$ the House of Lords confirmed the traditional view that duress could never be a defence to a charge of murder. ${ }^{113}$ The decision seems to be grounded in the argument that the law should not recognize that individuals have the liberty to choose that one innocent citizen should die rather than another. ${ }^{114}$ Ashworth has criticized this reasoning on the basis that it seems to treat duress as a justification rather than an excuse: because the killing of an innocent person is unjustified, the judges seemed to conclude that duress should not be available as a defence. The court's view is also difficult to reconcile with a variety of other situations in which killings have been regarded as deserving of a (partial) excuse (without, however, justifying the defendant's conduct), for example where the defendant was intoxicated or had been provoked. ${ }^{115}$ J.C. Smith has argued along similar lines:

as the killing of an innocent person was something of which [the Law Lords] could never approve, duress could never be a

\footnotetext{
${ }^{107}$ Graham, above n 105; $R v Z$ [2005] 2 AC 467.

${ }^{108} R v$ Shayler [2001] EWCA Crim 1977.

${ }^{109} R v$ Sharp [1987] QB 853.

${ }^{110}$ [2005] UKHL 22 [18] (Lord Bingham).

${ }^{111}$ Some common law commentators still argue that duress should be seen as a justification rather than an excuse, see e.g. P. Westen and J. Mangiafico, 'The Criminal Defense of Duress: A Justification, Not an Excuse-And Why It Matters' (2003) 6 Buff Crim L Rev 833.

112 [1987] AC 417.

${ }^{113}$ This was extended in Gotts, above $\mathrm{n} 100$, to encompass cases of attempted murder.

${ }^{114}$ Ashworth, above n 33, 213.

115 Ibid.
} 
defence to murder, however grave the threats involved. If they had considered that the question was whether the defendant deserved to be punished, or ought to be excused, they might have reached a different result. ${ }^{116}$

While duress remains unavailable as a defence to murder, ${ }^{117}$ it seems clear now that where it does apply, it operates as an excuse.

Not all instances of duress stem from human conduct, however. The law takes account of this by allowing for the defence of 'duress of circumstances' ${ }^{118}$ This comes into play where a person commits an offence not as the result of someone demanding 'commit this offence or else' but as a consequence of a threatening state of affairs, such as faced the defendants in Dudley and Stephens. ${ }^{119}$ As is well known, they were shipwrecked sailors threatened by starvation who resorted to killing and eating their cabin boy. They were convicted, but later pardoned; the modern law may well come to a similar result by condemning the act but excusing the actors, although this step has not yet been taken in any English case. The Law Commission, for one, has recently recommended that duress should be available as a full defence to murder; ${ }^{120}$ even going so far as saying that some instances of duress can justify murder as opposed to merely excusing it. ${ }^{121}$ As with duress by threats, the defence is available only where the defendant's acts were coerced by an imminent fear of death or serious injury. ${ }^{122}$

Duress of circumstances is best regarded as an excuse: instances often involve emergencies which prompt the defendant to react quickly, in circumstances where compliance with the law could not be reasonably expected of him. Thus, in DPP v Jones ${ }^{123}$ the defendant was attacked in the car park of a pub. Even though he knew himself to be intoxicated, he drove a short distance to escape his attackers. His conduct (drink-driving) was held to be excused.

Necessity, by contrast, is generally seen as a justification. ${ }^{124}$ It has mostly

\footnotetext{
${ }^{116} \mathrm{~J}$ C Smith, above n 6, 12.

${ }^{117}$ The Law Commission has recently suggested introducing duress as a full defence for murder and attempted murder, see Murder, Manslaughter and Infanticide, above n 74, [6.36 ff].

${ }^{118}$ See $R v$ Willer (1986) 83 Cr App R 225; Rv Conway [1989] QB 290.

119 (1884-85) LR 14 QBD 273.

${ }^{120}$ The Law Commission, Murder, Manslaughter and Infanticide, above n 74, [6.36-6.72].

${ }^{121}$ They give the example of the rope-climber whose fallen companion is dragging them both to oblivion: see The Law Commission, Murder, Manslaughter and Infanticide, above n 74, [6.61].

${ }^{122} \mathrm{R} v$ Martin (1989) 88 Cr App R 343; Abdul-Hussain, above n 102.

${ }^{123}$ [1990] RTR 33 .

${ }^{124}$ Ormerod, above n 42, 375 .
} 
been invoked in the contexts of medical treatment ${ }^{125}$ or road traffic offences, ${ }^{126}$ although the concept need not necessarily be so limited. ${ }^{127}$ The relevant cases require that the defendant's conduct amount to 'the lesser of two evils'. The defendant must thus assert that it was necessary to violate one legally protected interest in order to safeguard a competing interest which he believed more important. The defence is developed on a case-by-case basis, and remains unavailable as a defence to murder. ${ }^{128}$ This reflects concerns that too generous a 'lesser-evil justification' would threaten the authority of the law: if defendants were allowed to break laws whenever they could point to a lesser-evil justification, the general applicability of laws would be undermined. ${ }^{129}$ On the downside, the ambit of the defence is developed on an ad hoc basis. Uncertainties thus remain, to the extent that there seems to be an overlap with duress of circumstances. In fact, the terms necessity and duress of circumstances are at times used interchangeably, as in the case of Pommell. ${ }^{130}$ Police officers, when executing a search warrant, found the appellant lying in bed with a loaded sub-machine gun contrary to section 5 (1) (a) of the Firearms Act 1968. The appellant told the officers that, during the night, he had persuaded someone to give him the gun to prevent him from shooting some other people and that he intended to wait until the morning to give the gun to his brother to hand in to the police. The trial judge ruled that the appellant's failing to go to the police immediately deprived him of the defence of necessity. The Court of Appeal found that the judge was wrong to conclude as he did and that the proposed defence should have been left to the jury. Kennedy LJ who read the judgment, stated that while English law had not yet recognized a general defence of necessity, it had developed a (narrower) defence of duress of circumstances which had, prior to Pommell, been restricted to road traffic offences. Citing a passage by Professor Sir J C Smith, his Lordship concluded that there was no rea-

\footnotetext{
${ }^{125}$ See e.g. Fv West Berkshire Health Authority [1990] 2 AC 1; Re A (Children) (Conjoined Twins) [2001] Fam 147.

${ }^{126}$ See e.g. Pipe $v$ DPP [2012] EWHC 1821 (Admin). The defendant drove a boy to hospital who had been injured (albeit not life-threateningly) in a sports accident and was in much pain. His conviction for travelling at excess speed was quashed on appeal as the result of a misdirection on the necessity defence he sought to rely on.

${ }^{127}$ Ormerod, above n 42, 343.

${ }^{128} \mathrm{Re} A$ (Children), above $\mathrm{n} 125$, does not seem to have changed this position as the decision probably remains confined to its particular set of facts; furthermore, the different judges based their decisions on different rationales (self-defence vs necessity).

${ }^{129}$ A P Simester, J R Spencer, G R Sullivan and G J Virgo, Simester and Sullivan's Criminal Law-Theory and Doctrine (4th edn, 2010) 782.

${ }^{130}[1995] 2$ Cr App R 607.
} 
son to restrict the defence to road traffic, so that its possible application to the facts should have been left to the jury. Unfortunately, other than the reference to Smith, there is very little reasoning to support this conclusion in the judgment. In particular, there is no discussion whether this wider defence should continue to be referred to as 'duress of circumstances' and, if so, whether there is anything to distinguish it from a general necessity defence. Following Pommell, this has led to a conflation of the two in case law and literature, with 'duress of circumstances' and 'necessity' being used interchangeably.

(c) It has been suggested that Art. 31 (1) (d) takes up elements of (justifying) necessity and (excusing) duress, ${ }^{131}$ even though it speaks solely in terms of 'duress', and thus follows the common law model. The provision has been compared to the approach suggested by Judge Antonio Cassese in his dissenting opinion in Erdemovic, a case decided by the International Criminal Tribunal for the former Yugoslavia (ICTY) in 1997. ${ }^{132}$ Here, Cassese argued that in the context of crimes against humanity a defendant should theoretically be able to avail himself of the duress defence, but only if his giving in to the threat was a proportional response, in the sense that it reflected a choice for the lesser of two evils. ${ }^{133}$ In doing so, he presented duress as a variant of the necessity defense. ${ }^{134}$ As explained above, however, conflating necessity and duress in this way is highly problematic, because the person aiming to avail himself of a justification is making a very different claim from the person who hopes to escape punishment by virtue of an excuse: the former essentially asserts that what he did was not wrong; that, in fact, he had a right to act in the manner he did. By contrast, the person who relies on an excuse is conceding that he did indeed commit a legal wrong, but at the same

\footnotetext{
${ }^{131}$ Ambos, Defences, above n 3, 311; Eser, above n 58, [49].

${ }^{132}$ Prosecutor v Erdemovic, Separate and Dissenting Opinion of Judge Cassese, IT-96-22T, 7 October 1997. Erdemovic was a member of the Bosnian Serb army. He was charged with having killed several civilian Muslims in 1995. At trial, he claimed that his superiors had threatened to kill him if he did not participate in the shootings. The question before the ICTY Appeals Chamber was whether duress was available as a defence in these circumstances. The majority of the justices concluded that according to customary international law, duress was not a defence to murder. The dissenters, by contrast, asserted that duress could theoretically exonerate a defendant in this context, but they were adamant that such a defence would be subject to strict proportionality requirements and that because of the gravity of harm typically caused in crimes against humanity, it would be almost impossible for a defendant to establish the requisite proportionality.

${ }^{133}$ Prosecutor v Erdemovic, Separate and Dissenting Opinion of Judge Cassese, IT-96-22T, 7 October 1997, [41-42].

${ }^{134}$ LE Chiesa, 'Duress, Demanding Heroism and Proportionality: The Erdemovic Case and Beyond' (2008) 42 Vand J Transnat'1 741, Pace Law Faculty Publications (2007) Paper 404, 14, available at <http://digitalcommons.pace.edu/lawfaculty/404/> [accessed 26 July 2013].
} 
time is claiming that his act was understandable under the circumstances given and that he therefore should not be blamed for it. Indeed, in the Erdemovic case itself, the majority of the ICTY justices rejected duress as a defence to a crime committed against humanity on the presumption that duress, if successfully pleaded, would provide the defendant with a justification for his actions.

If one looks at the wording of Art. 31 (1) (d), the provision has much in common with traditional defences of pressure, and in the following, it will be argued that it can be interpreted so as to give rise to a duress defence alone (excluding necessity), and that it is best perceived as an excuse. ${ }^{135}$

Inasmuch as the provision requires 'duress resulting from a threat of imminent death or of continuing or imminent serious bodily harm against that person or another person' and that 'the person acts necessarily and reasonably to avoid this threat', its wording is reminiscent of common law duress. Notably, the provision is not restricted to threats 'made by other persons' (Art. 31 (1) (d) (i)) but also encompasses threats 'constituted by other circumstances beyond that person's control' (Art. 31 (1) (d) (ii)). It thus also applies to situations which English lawyers would term 'duress of circumstances'. I have above argued that this is best seen as an excuse, and the same arguments hold good for international criminal law. That Art. 31 (1) (d) excuses rather than justifies is reinforced by the fact that this provision is, at least on its face, even more generous than the English concept-and also more generous than the German provision on excusing necessity-in that it does not require any special relationship between the defendant and the person to be protected. Moreover, Art. 31 (1) (d) seems to envisage the availability of the defence also in cases of murder: ${ }^{136}$ it appears to apply to all crimes within the jurisdiction of the ICC. In this respect, the Rome Statute is clearly more generous than both English law (where neither duress nor necessity ${ }^{137}$ currently offer a defence to murder) and German law (where the balancing of life against life is never an option under the necessity defence of $\$ 34 \mathrm{StGB}$, and where under $₫ 35$ StGB the defendant will only be excused if he thereby aimed to protect his own life, limb or freedom or those of a person close to him). All this points in the direction of an excusatory defence.

However, it might be argued that the provision also entails elements that one might expect to find in a necessity defence. Notably, the provision envisages that

\footnotetext{
${ }^{135}$ Cassese's International Criminal Law, above n 65, 216.

${ }^{136}$ Eser, above n 58, [52].

${ }^{137}$ Doubt is cast on this by dicta in the civil case of Re A (Children) (Conjoined Twins) [2001] Fam 147, but no doctor charged with murder has since had to rely on the defence, so that its application to murder is still in doubt.
} 
'the person acts necessarily and reasonably to avoid this threat'. This requirement has been described as belonging to necessity, ${ }^{138}$ and could be taken as proof that the provision mixes up duress and necessity, creating a hybrid which is difficult to categorise as either excuse or justification.

ICC materials do not (yet) assist in categorising the provision. Although necessity and duress are the defences with the greatest practical relevance in international criminal law, ${ }^{139}$ they do not seem to have been relied on in ICC proceedings to date. One possible explanation is the aim of the ICC to bring to justice top- or mid-level perpetrators who tend to be the ones coercing rather than being coerced. As Professor Ambos has observed: '[t]he general structure of the defence (...) implies, on a factual level, pressure or coercion from "top to bottom". In other words, the people at the top cannot invoke duress because they cannot be coerced.' ${ }^{\prime}$ A further reason might lie in evidentiary problems. Has the hybrid nature of Art. 31 (1) (d) also a role to play? This appears doubtful, as conceptual uncertainties seem not to have in the past stopped those accused of atrocities from defending themselves with reference to notions of coercion and/or necessity. Indeed, there is evidence to suggest that tribunals presiding over crimes against humanity have tended to conflate the two defences throughout the history of international criminal law. ${ }^{141}$ That the ICC perpetuates such a conflation has been called unfortunate, ${ }^{142}$ and rightly so, for it is difficult to construct a coherent whole out of a mix of justificatory and excusatory elements.

One way in which coherence might be achieved is to conceive of Art. 31 (1) (d) as a provision that deals with duress (albeit by threats and by circumstances) alone, leaving it to the ICC to accept (the invariably more controversial, because justificatory) pleas of necessity (in the traditional sense of a 'lesser evil' defence) on a case by case basis pursuant to Art. 31 (3). The key to making sense of Art. 31 (1) (d), it is tentatively suggested, is then that it has nothing to do with necessity in the traditional sense: traditional necessity requires one evil to be objectively lesser than the other; Art. 31 (1) (d), by contrast, makes the perpetrator's subjective perception the yardstick of the balancing exercise (according to which he will be exonerated 'provided that [he] does not intend to cause a greater harm than

\footnotetext{
${ }^{138}$ Ambos, Treatise, above n 3, 356.

${ }^{139}$ Ibid, 348.

${ }^{140}$ Ibid, 360 .

${ }^{141}$ See Ambos, Treatise, above n 3, 348-351, identifying elements of necessity/duress defences in Nuremberg and Post-Nuremberg case law.

${ }^{142}$ Ambos, Treatise, above n 3, 356.
} 
the one sought to be avoided ${ }^{\prime 143}$ ). While, admittedly, the suggested interpretation is not true to Art. 31 (1) (d)'s legislative history-the provision was conceived as a compromise-it finds some support in the wording, as well as systematic considerations. It would also bring the statute more in line with comparative criminal law ${ }^{144}$ and aspirations to align duress by circumstances with duress by threats rather than necessity. Since on such a reading Art. 31 (1) (d) does not seem to cover necessity, it would be necessary to base it on Art. 31 (3). Such a defence could then be confined to situations in which the defendant is faced by a choice between two evils, one of which is certain to eventuate. Taking action in such a situation, averting the greater evil while accepting the lesser, might be regarded not just as excused but as justified: the actor acts not in order to commit an offence, but in order to prevent greater harm. The decisive factor is that anyone in his position would not just have acted in the same way, but would indeed have been morally required to act as he did. Importantly, for a necessity defence to apply, the lesser evil chosen by the defendant must be objectively lesser-thus, killing one person to prevent the death of a loved one would not be covered by the defence: objectively, the taking of one innocent life to save another can never be justified. The defendant might, however, be able to avail himself of the defence of duress under Art. 31 (1) (d) (whether by threats or circumstances), on the basis that he could not have been expected to withstand pressure presenting him with a choice between preserving his own life or that of a loved-one on the one hand, or that of a stranger on the other. The difference between the defensive claims relied on would be between a defence that requires proportionality in the objective sense (necessity) and one that requires proportionality in an objective-subjective sense (the evil is only lesser in the person's mind, but a reasonable person in his shoes might well have shared the perception that, subjectively, situation A is the lesser evil to situation B, whilst objectively-one life against another life-this conclusion is not true).

This interpretation can be squared with the wording of the statute in the following way: as pointed out above, Art. 31 (1) (d) demands that 'the person acts necessarily and reasonably to avoid this threat'. 'Necessarily' requires that no other means was available to the defendant by which to avoid the threat (or, rather, avoid acting on the threat). ${ }^{145}$ Most commentators argue that 'reasonably'

\footnotetext{
${ }^{143}$ Article 31(1)(d).

${ }^{144}$ Fletcher, Basic Concepts, above n 60, $138 \mathrm{ff}$.

${ }^{145}$ Ambos (Treatise, above n 3, 356) argues that 'the "necessary and reasonable reaction" element belongs traditionally to necessity'. This does not, however, interpret the words in the context of the provision, where they quite clearly qualify the avoidance of the threat rather than the nature
} 
should be understood as entailing an objective proportionality test. ${ }^{146}$ However, it is suggested that 'reasonably' could be interpreted to require no more than the 'reasonable person' standard familiar to common lawyers, requiring the defendant to have reacted as a reasonable person would have done in his position. If the threat is such that a reasonable person might have given in to it, then he will be exonerated (provided the defendant did not intend to cause a greater harm than the one sought to be avoided, i.e. did not act with dolus malus ${ }^{147}$ ). On such a reading, the 'reasonably' requirement does no more than go to the person's ability to withstand the pressure, reflecting the idea of Zumutbarkeit ('fair expectability"148 — what a person can be fairly expected to put up with in the relevant circumstances) in $\$ 35$ StGB: one can speak in terms of duress (proper) only where the threat is so powerful that it has so acted upon the defendant's mind as to make him believe he is left with no meaningful choice of conduct. Art. 31 (1) (d) could then be classified as a (more or less traditional common law) excusatory duress defence.

\section{Conclusion}

At first sight, the Rome Statute eschews the civilian classification of 'bars to responsibility', 'justifications' and 'excuses'; it does not mention these terms anywhere in its provisions on grounds of exclusion of criminal liability. However, on closer inspection it becomes clear that this classification does underlie the system of Art. 31 (1) Rome Statute.

The insanity defence focuses on the actor's capacity, which, as has been shown, is the same as a 'bar to responsibility'. A similar point can be made about intoxication, although, as seen, the scope of that defence has been much reduced in comparison to some domestic legal systems. Self-defence, in excluding mistaken self-defence from its ambit, points towards the conclusion that it is meant to justify rather than excuse. While the provision on 'duress' is based on common law concepts, the wording of the provision suggests that it is best regarded as an attempt to align duress with duress of circumstances (as opposed to necessity), and should as such be regarded as excusatory.

\footnotetext{
of the threat.

${ }^{146}$ Ambos, Treatise, above n 3, 1040.

${ }^{147}$ See Eser, above n 58, [59].

${ }^{148}$ See Fletcher, The Grammar of Criminal Law, above n 2, 322 ('conduct [which] is fairly to be expected of the offender').
} 
It is difficult to codify rules of international criminal law that are acceptable to all the representatives of the different legal traditions. Compromises are inevitable, and the Rome Statute is no exception: it draws from both civil law and common law concepts. As a result, it does not and cannot reflect the coherence and systematic integrity of either Rechtskreis. Naturally, views can also differ as to what makes a case deserving of a justification or an excuse. It is nevertheless important, if like cases are to be treated alike, that the law of defences be underpinned by a suitable and coherent system of categorization. On closer inspection, these underpinnings, which owe much to the civilian tradition, can be detected in Art. 31 (1), although it might have been preferable to have them more clearly identified and articulated. 